\title{
LAS PRIMERAS LITOGRAFÍAS DE HESIQUIO IRIARTE
}

\author{
Francisco de la MaZa
}

1. En 1968, en la Revista de Bellas Artes, Núm. 23, que pocos conocen y nadie lee, estudió y reprodujo las litografías de la novela Antonino y Anita o los Nuevos Misterios de México (1851) del escritor, pintor y escenógrafo francés Eduardo Rivière. Ignoraba entonces que hubiera escrito Rivière otra novela, en vista del éxito que tuvo la primera. Mas si ésta era mala, la segunda es peor. Llámese, tranquilamente, San Felipe de Jesús, Patrón de México, Novela Histórica y Religiosa, dedicada a las señoritas devotas de este Santo... Fue publicada por Delande Hermanos, en 1853. ${ }^{3}$

Bien sabía Rivière que no eran muchas las señoritas devotas de San Felipe de Jesús, pues nunca ha sido santo milagrero, pero tampoco ignoraba que, tocando la fibra cordial nacionalista, las señoritas, las señoras y hasta algunos varones, comprarían su libro.

Añade que la obra fue "escrita en francés... por el autor de Antonio y Anita o los Nuevos Misterios de México" y que está "adornada con estampas litográficas compuestas y dibujadas" por él y que fue traducida por L. C. que, por lo pronto ignoramos quién sea.

Como literariamente es deplorable, lo más importante de la novela es el grupo de dibujos litografiados por el excelente artista Hesiquio Iriarte, en la Litografía de Murguía. Parecen ser los primeros trabajos de Iriarte.

2. "Nacimiento de San Felipe de Jesús" .El niño ya santo, pues lleva aureola, tiene como unos tres años de edad (!), si no es que más, gordo y bien plantado, está en su cama, recargado en aquellas almohadas cilíndricas, duras pero decorativas, con sus flecos y borlas en los extremos, que se usaron en el siglo pasado; las amplísimas sábanas y la colcha bordada se abren para mostrar el desnudo y casi atlético cuerpo del niño,

\footnotetext{
${ }^{1}$ Agradezco la noticia, el préstamo del libro y el permiso de sacar las fotografias de las litografías, a mi amigo y gran bibliófilo don Ignacio Conde.
} 
mientras una dama - ¿su madre? - se hinca en la misma cama y lo adora. El padre y dos vecinas, envueltas, sin darse cuenta, en haces luminosos que vienen de un sol con el JHS, están también arrobados.

3. "La tempestad". El joven fraile San Felipe va a Filipinas en la Nao de la China. Está en la proa con otros frailes. Poco sabía Rivière de naves antiguas, pues pone la proa chata, aunque eso sí, no olvida ponerle el mascarón, que es entre tapir y tiburón. La vela se hincha al revés.

4. "Sueño de San Felipe de Jesús". Duerme al santo al fondo en una cama de burgués rico. Un ángel, con espada flamígera en la diestra, espanta a unos diablos que son unos señores de levita, con largas cabelleras y sus cuernecillos en la frente.

El ángel, hermoso y regordete, viste túnica talar y, a la manera del Barroco, luce su pierna derecha desnuda, del pie a la ingle, como demostrando su diferencia juvenil con los demonios.

5. "Apoteosis de San Felipe". Cuatro ángeles robustos lo llevan por el aire, aunque más parece que quicre dejarse caer hacia adelante. Poca devoción podrían tener las señoritas mexicanas para este santo dibujado por Rivière, tan joven, tan gordo, tan sin historia y sin antecedentes taumatúrgicos. En la parte baja el águila mexicana, volteando a la izquierda y posando sus garras, no sobre el tunal, sino sobre una rama más fina de no sabemos qué arbusto.

6. "Adelina". Esta es, por romántica y fina, la mejor litografía del libro. Representa a la dama principal de la novela recargada en un antepecho de la Alameda, de una frondosa Alameda inimaginada, con una fuente formada por un tazón que sostiene caprichosos niños desnudos. Adelina es una hermosa joven vestida con toda elegancia a la usanza de la época, con un velo blanco que le da vuelta por todos lados.

7. "El niño Azemus". En una nave o galería de columnas dóricas, una diablesa con culebras capilares, como Medusa y un diablo-caballero, disputan sobre el niño Azemus, un pequeño héroe de la novela. Azemus es encantador. Es un retrato ideal de los niños de mediados del siglo pasado, con trajecito de pantalón corto, medias $y$ casaca, con abundante y rizada cabellera rubia. 